\title{
HUBUNGAN PARITAS DENGAN TINGKAT NYERI PERSALINAN KALA I FASE AKTIF PADA IBU BERSALIN DI BIDAN PRAKTEK MANDIRI PADANG TAHUN 2018
}

\author{
Meta Rikandi ${ }^{1}$ \\ ${ }^{1}$ STIKes Alifah Padang \\ Email : meta.rikandi@gmail.com
}

\begin{abstract}
Abstrak
Persalinan merupakan proses pengeluaran hasil konsepsi (janin dan plasenta) yang telah cukup bulan dan dapat hisup diluar kandungan melalui jalan lahir atau jalan lain dengan bantuan atau tanpa bantuan (kekuatan sendiri). Penelitian ini bertujuan untuk mengetahui hubungan paritas dengan nyeri persalinan kala I di Bidan Praktek Mandiri Padang Tahun 2018. Populasi berjumlah 30 orang, analisis data yang digunakan yaitu univariat dan bivariat. Hasil Penelitian didapatkan 50\% orang primipara dan multipara. Hasil uji statistik terdapat hubungan secara sifnifikan antara paritas dengan nyeri persalinan kala I pada ibu bersalin di bidan praktek mandiri padang tahun 2018 dengan nilap $\mathrm{p}=0,000$. Kepada bidan diharapkan harus lebih memperhatikan tingkat nyeri pasien dalam persalinan dengan menghadirkan pendamping saat persalinan sehingga nyeri dapat diatasi.
\end{abstract}

Kata Kunci : paritas, nyeri persalinan

\begin{abstract}
Childbirth is a process of expending the conception (fetus and placenta) that has been sufficient for months and can be out of the womb through the birth canal or other path with help or without assistance (own strength). This study aims to determine the relationship of parity with labor pain in the first stage of Padang Practice Midwife Year 2018. Population amounted to 30 people, the analysis of data used are univariate and bivariate. The results of this study were $50 \%$ primiparous and multipara. The result of the statistical test shows that there is a significant relationship between parity and labor pain in the first stage of maternal womb in the self-employed midwife in 2018 with $\mathrm{p}=$ 0,000 . To the midwife is expected to pay more attention to the patient's pain level in labor by presenting the companion during labor so that the pain can be overcome.
\end{abstract}

Keywords: Parity, labor pain

\section{PENDAHULUAN}

Persalinan merupakan proses pengeluaran hasil konsepsi (janin dan plasenta) yang telah cukup bulan dan dapat hisup diluar kandungan melalui jalan lahir atau jalan lain dengan bantuan atau tanpa bantuan (kekuatan sendiri). Proses ini dimulai dari adanya kontraksi persalinan sejati yang ditandai dengan perubahan servik secara progresif dan diakhiri dengan kelahiran plasenta (Sulistyawati, 2010). Proses persalinan merupakan kejadian alamiah yang menyertai siklus hidup wanita untuk mengeluarkan hasil konsepsi (janin dan plasenta). Akan tetapi proses ini member makna yang berbeda-beda tiap individu dan menjadikan suatu pengalamn yang unik. Kondisi ini dikarenakan berbagai faktor salah 
satunya adalah adanya nyeri selama proses persalinan. Nyeri persalinan mulai timbul pada tahap kala I yang berasal dari kontraksi uterus dan dilatasi serviks, dengan makin bertambahnya baik lama frekuensi kontraksi uterus, nyeri yang dirasakan akan bertambah kuat (Lestari, dkk, 2012).

Nyeri persalinan merupakan pengalaman subjektif tentang sensasi fisik yang terkait kontraksi uterus, dilatasi dan penipisan serviks, serta penurunan janin selama persalinan. Respon fisiologis terhadap nyeri meliputi tekanan darah, denyut nadi, pernapasan, keringat, diameter pupil dan ketegangan otot (Arifin, 2008).

Nyeri persalinan dapat menyebabkan kecemasan pada pasien, menyebabkan timbulnya hiperventilasi sehingga kebutuhan oksigen meningkat, kenaikan tekanan darah dan berkurangnya motilitas usus serta vesika urinaria. Selain itu kecemasan atau stress yang tinggi akan menyebabkan pelepasan hormon katekolamin dan steroid yang menyebabkan terjadinya ketegangan otot polos dan vasokontriksi pembuluh darah sehingga terjadi penurunan kontraksi uterus, penurunan sirkulasi uteroplasenta, pengurangan aliran darah dan oksigen ke uterus, serta timbulnya iskemia uterus yang membuat impuls nyeri bertambah banyak.

Berdasarkan fenomena diatas, penulis tertarik untuk melakukan penelitian tentang " Hubungan paritas dengan nyeri persalinan Kala I Fase Aktif Pada Ibu bersalin di Bidan Praktek Mandiri Padang Tahun 2018”.

\section{Rumusan Masalah}

Bertitik tolak dari uraian latar belakang diatas, maka perumusan masalah pada penelitian ini adalah "Hubungan paritas dengan nyeri persalinan Kala I Fase Aktif Pada Ibu bersalin di Bidan Praktek Mandiri Padang Tahun 2018”.

\section{METODE PENELITIAN}

Jenis penelitian ini adalah deskriptif analitik dengan menggunakan pendekatan cross sectional. Peneliti ingin melihat gambaran sekaligus hubungan semua variabel. Dalam penelitian cross sectional dimana variabel independen (paritas) dan variabel dependen (nyeri persalinan kala I) diukur pada waktu yang bersamaan.

\section{HASIL}

a. Analisis Univariat

1) Distribusi Rerata Umur Ibu Bersalin di Bidan Praktik Mandiri Padang Tahun 2018

Tabel 1 Distribusi Umur Ibu Bersalin di Bidan Praktik Mandiri Padang

\begin{tabular}{ccccc}
\hline Variabel & Mean & SD & $\begin{array}{c}\text { Minimal } \\
- \\
\text { Maksimal }\end{array}$ & 95\% CI \\
\hline Umur & 27,03 & 5,034 & $17-37$ & $25,15-28,91$ \\
\hline
\end{tabular}

Berdasarkan tabel 1 didapatkan bahwa rata-rata umur ibu bersalin adalah 26,33 tahun dengan variasi 5,034 tahun. Umur 
termuda ibu bersalin adalah 17 tahun dan umur tertua 37 tahun. Hasil analisis dapat disimpulkan bahwa 95\% diyakini bahwa rata-rata umur ibu hamil berada di antara 25,15 tahun sampai dengan 28,91 tahun.

2) Distribusi Paritas Ibu Bersalin di Bidan Praktik Mandiri Padang Tahun 2018

Tabel 2 Distribusi Paritas Ibu Bersalin di Bidan Praktik Mandiri Padang Tahun 2018

\begin{tabular}{ccc}
\hline Paritas & Jumlah (n) & $\begin{array}{c}\text { Presentase } \\
(\mathbf{\%})\end{array}$ \\
\hline Primipara & 15 & 50,0 \\
Multipara & 15 & 50,0 \\
\hline Total & $\mathbf{3 0}$ & $\mathbf{1 0 0 , 0}$ \\
\hline
\end{tabular}

Distribusi paritas ibu bersalin pada responden paritas primipara sebanyak 15 orang $(50,0 \%)$. Sedangkan paritas multipara sebanyak 15 orang $(50,0 \%)$.

\section{b. Analisis Bivariat}

\section{3) Hubungan Paritas Ibu dengan Skala} Nyeri Kala I Fase Aktif pada Ibu Bersalin

Tabel 3 Hubungan Paritas Ibu dengan Skala Nyeri Kala I Fase Aktif pada Ibu Bersalin di Bidan Praktik Mandiri Padang

\begin{tabular}{cccc}
\hline Paritas & Mean & SD & P value \\
\hline Primipara & 7,11 & 0,333 & \multirow{2}{*}{0,000} \\
Multipara & 3,67 & 1,633 & \\
\hline
\end{tabular}

Menurut tabel 3 dapat terlihat bahwa rata-rata skala nyeri paling berat dirasakan oleh ibu dengan paritas primipara atau ibu dengan pengalaman pertama kali melahirkan yang itu dengan rata-rata nyeri sebesar 7,11 atau dikategorikan nyeri berat dengan variasi 0,333 .

\section{PEMBAHASAN}

Seiring dengan meningkatnya pengalaman lahir ibu ternyata diikuti dengan semakin rendah tingkat nyeri yang dirasakan ibu. Rata-rata tingkat nyeri ibu dengan paritas multipara yaitu 3,67 dengan variasi 1,633 . Hasil uji statistik diperoleh $p$ value $=0,000$ artinya secara statistik ratarata nyeri ibu bersalin berhubungan dengan paritas ibu bersalin.

Dipandang dari proses persalinan, rasa nyeri sebenarnya tidak diperlukan. Kontraksi rahimlah yang membenatu proses pengeluaran bayi. Nyeri juga menimbulkan beberapa perubahan yang sangat signifikan dalam tubuh ibu bersalin, sedangkan menurut Judha (2012) nyeri dapat terjadi pada ibu primi maupun multi yang disebabkan karena adanya peregangan perineum dan vulva, adanya tekanan uterus bertical saat kontraksi dan adanya penekanan bagian terendah janin secara progresif pada fleksus lumboskral, kandung kemih, dan struktur sensitif panggul yang lain. 
Nyeri persalinan menurut Maryunani (2010) adalah nyeri kontraksi uterus yang dapat mengakibatkan peningkatan aktifitas sistem saraf simpatis, perubahan tekanan darah, senyut jantung, pernapasan, dengan warna kulit dan apabila tidak segera diatasi maka akan meningkatkan rasa khawatir, tegang, takut dan stress. Munculnya nyeri sangat berkaitan erat dengan reseptor dan adanya rangsangan. Reseptor nyeri yang dimaksud adalah nociceptor, merupakan ujung-ujung saraf yang sangat bebas yang memiliki atau bahkan myelin yang tersebar pada kulit dan mukosa, khususnya [ada organ visceral, persendian, dinding arteri, hati, dan kandung empedu. Reseptor nyeri dapat memberikan respon akibat adanya stimulasi atau rangsangan. Stimulasi tersebut dapat berupa zat kimiawi seperti histamine bradikinin, prostaglandin, dan macammacam asam yang dilepas apabila terdapat kerusakan pada jaringan akibat kekurangan oksigen. Stimulasi yang lain dapat berupa termal listrik atau mekanis (Maryunani, 2010).

Selanjutnya Stimulasi yang diterima oleh respon tersebut ditransmisikan berupa impuls-impuls nyeri ke sumsum tulang belakang oleh dua jenis serabut yang bermyelin rapat atau serabut A (delta) dan serabut lamban (serabut C). Impuls-impuls yang ditransmisikan ke serabut C. Serabutserabut eferen masuk ke spinal melalui akar dorsal (dorsal root), dorsal horn sendiri terdiri atas beberapa lapisan atau laminae yang saling bertautan. Diantara lapisan dua dan tiga membentuk substansi gelatinosa yang merupakan saluran utama impuls. Kemudian impuls nyeri menyeberang sumsum tulang belakang pada interneuron dan bersmabung ke jalur spial asendens yang paling utama, yaitu jalur spinothalamic tract (SST) atau jalur spinothalamus dan spinoreticular tract (SRT) yang membawa informasi mengenai sifat dan lokasi nyeri. Kemudian pada proses transmisi terdapat dua jalur mekanisme terjadinya nyeri yaitu jalur opiate dan jalur nonopiate, jalur opiate ditandai dengan pertemuan reseptor pada otak yang terdiri jalur soinal desendens dari thalamus yang melalui otak tengah dan medulla ke tanduk dorsal tulang belakang yang berkonduksi dengan nociceptorimpuls supresif. Serotonim merupakan neurotransmitter dan impuls supresif. Sistem supresif lebih mengaktifkan stimulasi nociceptor yang ditransmisikan oleh serabut A. Jalur nonopiate merupakan jalur desenden yang tidak memberikan respon terhadap nalox-one yang kurang banyak diketahui mekanismenya (Maryunani, 2010). 
Ibu primipara mengalami persalinan yang lebih panjang sehingga akan cepat merasa letih. Hal ini menyebabkan peningkatan nyeri. Rasa nyeri yang terjadi selama kala I fase aktif juga disebabkan oleh kontraksi uterus yang terus meningkat untuk mencapai pembukaan serviks yang lengkap. Semakin bertambahnya volume dan frekuensi kontraksi uterus maka rasa nyeri juga akan semakin meningkat. Rasa nyeri akan terus meningkat seiring dengan bertambanya pembukaan dari $1 \mathrm{~cm}$ sampai pembukaan lengkap $10 \mathrm{~cm}$ (Wahyuningsih, 2014).

Nyeri persalinan akan bertambah kuat seiring dengan bertambahnya pembukaan, puncak nyeri terus meningkat sampai dengan pembukaan lengkap $10 \mathrm{~cm}$. Hal ini disebabkan oleh anoksia miometrium dimana terjadi kontraksi otot selama periode anoksia yang relatif menyebabkan nyeri. Apabila relaksasi uterus antara saat terjadi kontraksi tidak cukup memungkinkan terjadinya oksigenasi yang adekuat, maka nyeri dirasakan semakin bertambah (Harry \& William, 2003).

Nyeri merupakan sesuatu yang kompleks, sehingga banyak faktor yang mempengaruhinya. Salah satunya adalah usia. Pada penelitian ini responden berada pada rentang usia 17 - 37 tahun. Usia mempunyai hubungan pengalaman terhadap suatu masalah kesehatan atau penyakit dan pengambilan keputusan. Seseorang yang berusia lebih tua akan mampu merespon terhadap stressor yang dihadapi daripada seseoran yang berusia lebih muda. Setiap orang memiliki cara yang berbeda dalam mengatasi dan menginterpretasikan nyeri. Cara seseorang berespon terhadap nyeri adalah akibat banyak pengalaman rasa nyeri selama rentang hidupnya (Potter \& Perry, 2005).

Faktor lain yang mempengaruhi nyeri persalinan diantarannya adalah kecemasan dan stress dimana jika ibu bersalin tidak mampu mengatasi kecemasan yang dialaminya maka nyeri yang dirasakan juga bertambah. Jumlah persalinan juga mempengaruhi nyri pada persalinan berdasarkan gambar 4 bahwa sebagian besar $(52 \%)$ yaitu 11 ibu bersalin di BPM Kota Padang. pernah melahirkan 2-3. Hal ini menunjukkan bahwa pengalaman nyeri sebelumnya berpengaruh karena ibu bersalin yang pernah merasakan rasa nyeri yang sama akan mampu mengendalikan dirinya sehingga akan dapat beradaptasi dengan nyeri yang dirasakan, sehingga dalam penelitian ini ditemukan hampir separoh $(46,7 \%)$ yaitu 7 orang ibu bersalin mengalami nyeri berat. Lingkungan dan individu pendukung merupakan salah satu 
faktor yang mempengaruhi nyeri persalinan karena saat ibu bersalin mengalami nyeri akan membutuhkan seseorang yang membuat dirinya merasa nyaman sehingga saat kenyamanan itu didapatkan maka rasa nyeri yang dirasakan juga akan berkurang. Makna nyeri tergantung pada kondisi dan interpretasi klien terhadap makna nyeri tersebut. Cara seseorang berespon terhadap nyeri adalah akibat dari banyak kejadian nyeri selama rentang hidupnya. Hal tersebut sesuai dengan hasil penelitian yang dilakukan oleh Argi Virgona Bangun, dkk (2013) bahwa intensitas nyeri sebelum diberikan aroma terapi lavender 4,80 dengan intensitas nyeri terendah 2 dan tertinggi 10. Dari tingkat kepercayaan pasien disimpulkan bahwa 95\% diyakini bahwa rata-rata intensitas nyeri antara 2,99 sampai 6,61.

Sensasi nyeri umumnya berat dirasakan oleh ibu yang baru menjalani persalinan anak pertama. Rasa tidak nyaman dari kontraksi mengakibatkan 2 hal yaitu: perubahan serviks dan iskemia rahim yang dapat menyebabkan nyeri viseral, nyeri ini berasal dari bagian bawah abdomen dan menyebar kedaerah lumbal punggung dan menurun kepaha biasanya ibu mengalami nyeri ini hanya selama kontraksi dan bebas dari rasa nyeri pada interval antara kontraksi, rasa nyeri ini tidak serupa dengan kram yang dirasakan saat menstruasi (Mander, 2005).

\section{UCAPAN TERIMA KASIH}

Penulis mengucapkan terima kasih sedalam-dalamnya kepada Yayasan Alifah Nur Ikhlas Padang yang telah memberikan kesempatan untuk melaksanakan penelitian serta memberikan bantuan dana untuk penelitian ini. Ketua STIKes beserta rekan-rekan, Dinas Kesehatan dan Kepala Puskesmas beserta jajaran yang telah memberikan kesempatan untuk melakukan penelitian di Wilayah Puskesmas Ulak Karang Padang, Bidan Praktek Mandiri Kota Padang.

\section{DAFTAR PUSTAKA}

Diananda, Rama. 2008. Mengenal Seluk Beluk Kanker, Yogyakarta : Kata Hati

Hartati, 2010. Waspadai 4 Kanker Ganas Pembunuh Wanita, Yogyakarta : C.V ANDI

Mubarak, 2010. Ilmu Keperawatan Komunitas Konsep dan Aplikasi, Jakarta : EGC

Notoatmodjo, 2008. Perilaku dan Promosi Kesehatan, Jakarta : Rineka Cipta , 2011. Perilaku dan Promosi Kesehatan, Jakarta : Rineka Cipta

Pudiastuti, Ratna Dewi. 2014. Kebidanan Komunitas, Jakarta : EGC

Rasjidi, 2008. Waspada Kanker Pada Pria \& Wanita, Yogyakarta : Siklus 
, 2010. Waspada Kanker Pada Pria \& Wanita, Yogyakarta : Siklus

Rokhmawati, 2011. Inspeksi Visual Asam Asetat, Jakarta

Rukiah, dkk. 2014. Asuhan Kebidanan Ibu Hamil. Jakarta : CV. Trans Media

Samadi, Heru Priyanto. 2010. Yes,I Know Everything About Kanker Serviks. Solo: Metagraf Creative Imprint Of Tiga Serangkai

Setiadi. 2007. Konsep dan Penulisan Riset Keperawatan, Surabaya : EGC

Setiati, Eni. 2009. Waspadai 4 Kanker Ganas Pembunuh Wanita. CV Andi Offset Cetakan Pertama: Yogyakarta
Suprijanto, H. 2008. Pendidikan Orang Dewasa. Bumi Aksara : Jakarta

Wawan, 2011. Teori dan Pengukuran Pengetahuan, Sikap dan Perilaku Manusia, Yogyakarta : Nuha Medika 